\title{
Determination of platinum group metals in dust, water, soil and sediments in the vicinity of a cement manufacturing plant
}

\author{
Vhahangwele Matodzi ${ }^{1} \cdot$ Malebogo Andries Legodi ${ }^{1}$. Nikita Tawanda Tavengwa ${ }^{1}$
}

Received: 19 August 2019 / Accepted: 7 May 2020 / Published online: 16 May 2020

(c) Springer Nature Switzerland AG 2020

\begin{abstract}
Global economic growth has led to an increase in cement production to meet the demand of infrastructural development over the past decades. This has resulted in cement factories being the major sources of dust pollution. Dust emanating from the cements plants deposits on buildings, roadways, on road pavements and plants. The purpose of this study was to determine the concentration of platinum group metals (PGMs) emitted with cement dust on a dust suppressed roadway next to a cement factory in Waterberg, South Africa. The concentrations of PGMs were determined using inductively coupled optical emission spectrometry. This region is well known for large reserves and mining of PGMs such as Pt, Rh, $\mathrm{Ru}$ and Pd. The highest concentration in the dust samples collected along the roadway was that of Pt followed by Ru, Rh and Pd. The concentrations of Pt, Ru, Rh and Pd in soil samples decreased with the increase of depth. Water concentration of PGMs decreased at each sampling point in the following order; $\mathrm{Pt}>\mathrm{Ru}>\mathrm{Rh}>\mathrm{Pd}$. Sediments samples were also sampled along the Crocodile River for characterisation of physico-chemical parameters. It was of great importance to also analyse PGMs in soils, water and sediments since, dust settles on them. Elevated concentrations of Pt were observed in all samples and the highest concentrations were partitioned to the small particle size fraction of $32 \mu \mathrm{m}$. The pH and electric conductivity $(\mathrm{EC})$ of the sediments were measured and the $\mathrm{pH}$ values increased while $\mathrm{EC}$ values decreased moving along the river. The most common minerals identified in the dust samples were quartz and calcites. Vehicular emissions were also found to be the major contributor to suspended particulate matter and atmospheric deposition of dust dominantly result from emission from the cement plant. The cement plant was the major polluter through atmospheric deposition of dust particles. The result also revealed that the $\mathrm{pH}$ of the Crocodile River was slightly alkaline which was influenced by the effluent from the cement plant.
\end{abstract}

Keywords Dust suppressants · Cement dust · Platinum group metals · Cement factory · Environment

\section{Introduction}

Thabazimbi local municipality is located within a belt of mining reserves of platinum, iron, chrome, limestone etc., and within the Bushveld region of South Africa. Bushveld igneous complex is well known area for its rich in platinum group metals (PGMs) and some of the principal mines from which these PGMs are obtained. Platinum $(\mathrm{Pt})$, palladium ( $\mathrm{Pd})$, Ruthenium and rhodium (Rh) (also referred to as platinum group metals (PGMs)) that are chemically and physically similar and these metals are released into the environment by anthropogenic activities such as road traffic and mining industries [1]. 85\% of the world's PGMs production is in South Africa, and has $82 \%$ of the world's economic resources [2]. There are also cement companies mining raw materials for cement production. Raw materials such as limestone and clay in the area are expected to contain some amounts PGMs.

Nikita Tawanda Tavengwa, nikita.tavengwa@univen.ac.za | 'Department of Chemistry, School of Mathematical and Natural Sciences, University of Venda, Private bag X5050, Thohoyandou 0950, South Africa. 
Due to availability of raw materials for cement production, there is cement plant located near Thabazimbi. The cement industry, due to the nature of its activities, is one of the leading polluters of the environment [3].

This cement industry is faced with the environmental issues of dust and its effects. Therefore, there is high possibility that PGMs might also be emitted with cement dust during pyro-processing from the plant to the surrounding environment. During cement manufacturing, dust emission usually occurs during quarrying and crushing, raw material storage, grinding and blending (in the dry process only), clinker production, clinker storage piles, grinding, and packaging and loading [4]. The largest emission source of dust within cement plants is the pyro-processing system which includes the kiln and clinker cooler exhaust stacks.

The PGMs are currently under the spotlight as they offer the dual attraction of rare, high-value precious metals as well as having major industrial uses [2]. Due to the expected development within the Waterberg area and the existing mining and metallurgical activities in the western arm of the bushveld igneous complex [5], there is concern regarding the future and current air quality in these regions. This led to the establishment of the Waterberg Priority Area ambient air quality monitoring network in 2012 to monitor the ambient air quality in the Waterberg Area.

Some people have expressed concern over inadequate dust control measures from cement plants because fallout from quarry dumps containing cement dust can be a major issue to residents residing close to these companies (USEPA 1994) [6]. Health effects due to the exposure to constituents of cement dust on organ system in humans have been described in literature. According to Nurbiyantaro [7], exposure via inhalation of dust particles in the respiratory tract will cause a variety of lung function impairment. Chest pain, congestion, throat inflammation, cardiovascular disease and respiratory ailments are some of diseases that can be caused by air pollution [8]. The general outcome of occupational exposure to PGMs is adverse health effects in the respiratory tract and the skin with the potential of lowering the quality of life, contributing to a disabling illness [9]. PGMs have chronic effects that are characterised by the reduction in body mass and content of haemoglobin in the blood [9]. Concerns may also arise from the farmers who have to handle cement dust during the application to agricultural fields (USEPA 1998) [10]. The effects of dust on the agricultural area are determined by the concentration of dust particles in the ambient air, size distribution, deposition rate and its chemistry [11]. Irrigation using PGMs polluted water and dust deposition may cause contamination of agricultural soils to even deep lower layers.
In the past, it was common for many companies to indiscriminately discharge their wastes into the environment. This practice left governments to bear the cost of environmental clean-up. Due to environmental and health effects of cement dust and dust in general, many cement manufacturing companies are prioritizing minimization of the ambient particulate levels by reducing mass load emitted from the stacks [12]. A bulk of dust sample was analysed using modified three-step sequential extraction procedure called European Community Bureau of Reference ( $B C R$ ) which provide more information on the origin, physico-chemical availabilities, mobilisation, and transport of trace metals in natural environments $[13,14]$. This BCR sequential extraction method analyses different fractions of metals in the dust: acid-extractable (water soluble, exchangeable, and bound to carbonates), reducible (bound to Fe and Mn oxides), oxidizable (bound to sulphides and organic matter), and residual [15-17].

The primary aim of this study was to determine the contribution of road dust to PGMs such as Pt, Pd, Rh and Ru next to a cement plant in Thabazimbi Municipality in South Africa. Many studies conducted thus far are focused mainly on the vehicular emission of PGMs on dusty roadway. However, industries such as cement factory can also contribute towards an elevated level of PGMs in the environment [18-20]. Therefore, this study focusses on the determination of PGMs emitted from a cement plant to establish severity of their contamination on the surrounding environment.

\section{Materials and methods}

\subsection{Analytical reagents}

Analytical grade chemicals for sequential extraction $\mathrm{H}_{2} \mathrm{O}_{2}$, $\mathrm{NH}_{2} \mathrm{OH} \cdot \mathrm{HCl}, \mathrm{CH}_{3} \mathrm{COONH}_{4}, \mathrm{CH}_{3} \mathrm{COOH}$ and $\mathrm{HNO}_{3} / \mathrm{HCl}$ for aqua regia were obtained from Merck (Johannesburg, South Africa). Calibration standards were prepared using PGMs standards metal solutions ( $1000 \mathrm{mg} \mathrm{L}^{-1}$ ) purchased from Merck (Darmstadt, Germany).

\subsection{Materials}

Mesh sieves $(125,75$ and $32 \mu \mathrm{m})$ bought from Lasec (Johannesburg, South Africa) were used to sort the dust into different sizes. Mechanic shaker bought from Retsch (Johannesburg, South Africa) was used to shake the sieves. A refrigerator bought from Labtech (Johannesburg, South Africa) was used to store the samples at $4.0^{\circ} \mathrm{C}$. CNW water bath thermostatic vibrator purchased from Lasec (Johannesburg, South Africa) was used to mechanically shake the samples in $50 \mathrm{~mL}$ centrifuge vials. An MRC centrifuge 
purchased from Retsch (Johannesburg, South Africa) was used to separate the residue and the extracts in the vials. All dilutions were done using ultrapure water purchased from Milli Q system (Millipore, France). A portable Multiprobe Boeco $\mathrm{pH}$ meter purchased from Rochelle (Johannesburg, South Africa) was used to measure the $\mathrm{pH}$ and electrical conductivity (EC), temperature and total dissolved solids (TDS).

\subsection{Instruments}

Measurements were carried out with a sequential, axially viewed ICP-OES 9000 Shimadzu equipped with a Mein hard nebulizer, a glass cyclonic spray chamber and ICP WinLab software Data System. Argon (purity > 99.995\%) supplied by BOC gases a member of Linde group (South Africa), was used to sustain plasma and as carrier gas. Axial view was used for metals determination. The emission intensities were obtained for the most sensitive lines free of spectral interference. The conditions of ICP-OES are indicated in Table 1. The calibration standards were prepared by diluting the stock multi-elemental standard solution $\left(1000 \mathrm{mg} \mathrm{L}^{-1}\right)$ in $0.5 \%(\mathrm{v} / \mathrm{v})$ nitric acid containing all analysed PGMs elements supplied by Merck (Darmstadt, Germany). For the calibration curve, the following standard solutions (blank, 5, 10, 25, 50, 100, 200, 500, $2000 \mu \mathrm{g} \mathrm{L}^{-1}$ ) were prepared from a multi-element solution $\left(10 \mathrm{mg} \mathrm{L}^{-1}\right)$. The dilutions were achieved using MilliQ ${ }^{\circ}$ ultra-pure water. The X-ray diffraction powder pattern was recorded at $26^{\circ} \mathrm{C}$ using Bruker AXS (Karlsruhe, Germany). Measurements were performed using a multi-purpose $\mathrm{X}$-ray diffractometer D8-Advance from Bruker operated in a continuous scan in locked coupled mode with Cu-Ka $\left(\lambda K a_{1}=1.5406 \AA\right)$ radiation and Lynx Eye (Position sensitive detector). The Bruker handheld S1 Titan XRF (Cramerview, South Africa) spectrometer equipped with a $\mathrm{Rh}$ anode $\mathrm{X}$-ray tube and a maximum voltage of $50 \mathrm{kV}$ was employed for the dust analysis.

\subsection{Sampling area}

The cement plant shown in Fig. 1 is situated next to several agricultural fields cultivated with pastures (GPS coordinates $24^{\circ} 98^{\prime} 66 \mathrm{~S}, 27^{\circ} 54^{\prime} 65 \mathrm{E}$ ) and a busy gravel roadway parallel to the Crocodile River flowing towards the west in Koedoeskop which falls under the jurisdiction of the Thabazimbi Local Municipality and the Waterberg District, South Africa. The gravel roadway joins the R511 road on both its ends. Thabazimbi area is characterised by three prominent east-west trending mountain ranges and the majority of the mining operations take place in these mountains where the deposits of PGMs occur. The cement plant has a production capacity of 1.2 million tonnes per year [21]. There is Northam Platinum Mine on the far west of the cement plant. The gravel road is used by heavy traffic coming and going from the cement plant and there is also heavy traffic of trucks transporting raw minerals from the nearby mines. Water from the Crocodile River is used for irrigation by the farmers, where the main agricultural activity is centred on pastures. Water is also channelled from the Crocodile River to the cement plant and used for cooling the rotary kiln during the production of the clinker. During processing, water gets contaminated with pollutants released from the formation of the clinker. Contaminated water is treated with lime to precipitate the pollutants and then released back into the river. This water is also sprayed over the gravel roadway to suppress dust.

\subsection{Sample collection}

The dust samples (20 samples in total) were collected in summer using a brush and a pan along a gravel roadway at a distance of $1 \mathrm{~km}$ apart from one end of the roadway to the other end of the gravel road passing by the cement plant. A bulk of dust was sampled next to the cement plant for analysis of PGMs in different fractions, composition of PGMs in different particle size fractions, XRD, and XRF characterization and measurement of $\mathrm{pH}$ and EC. Sediments samples were collected by hand (with latex gloves and plastic spatula), along the Crocodile River put into cleaned ziplock plastic bags and taken to the laboratory in cooler boxes. Six soil samples were dug using a small garden fork and a spade for depth analysis and another sample was dug on a farm nearby the cement plant and put into ziplock plastics. Samples were dried at room temperature until a constant weight was achieved and separated into different particles size fractions $(125,75$ and $32 \mu \mathrm{m})$ in the laboratory. All the samples were originally stored in
Table 1 ICP-OES instrumental parameters for the analysis of platinum group metals

\begin{tabular}{llll}
\hline Parameter & Value & Parameter & Value \\
\hline Ignition mode & Normal (water) & Carrier gas & $0.6 \mathrm{~L} \mathrm{~min}^{-1}$ \\
RF generator power & $1.20 \mathrm{KW}$ & Air gas & $500 \mathrm{kPa}$ \\
Plasma-forming air flow rate & $10 \mathrm{~L} \mathrm{~min}^{-1}$ & Replicates & 3 \\
Gas flow auxiliary & $2 \mathrm{~mL} \mathrm{~min}^{-1}$ & Background correction & 2 points \\
Peristaltic pump flow rate & $1.8 \mathrm{~mL} \mathrm{~min}^{-1}$ & Plasma viewing & Axial \\
\hline
\end{tabular}




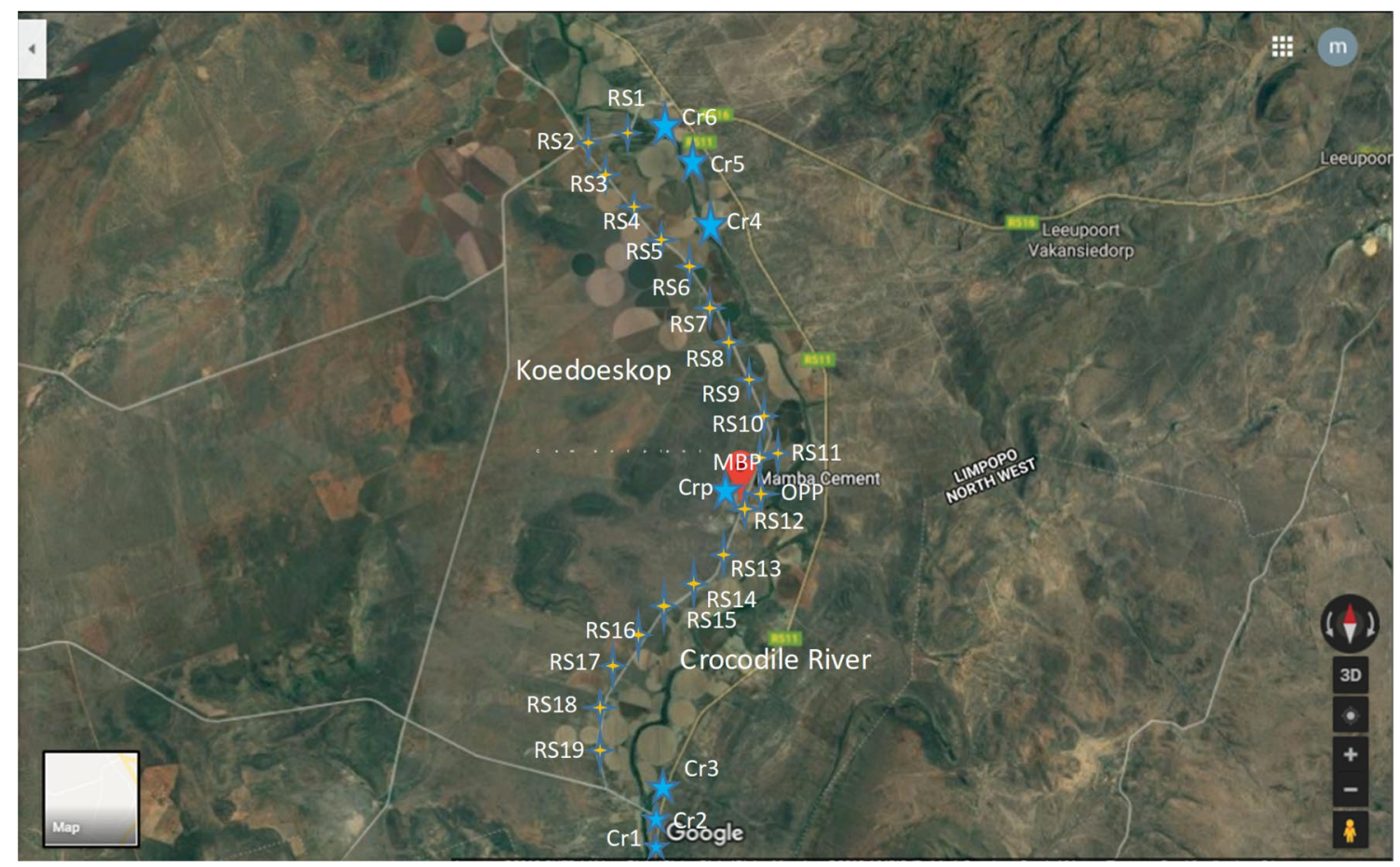

Fig. 1 Sampling sites for dust along the road (4-stars), water samples (5-stars) along the Crocodile River and factory effluent

paper and plastic bags until analysis. A total of 7 water samples were collected along the banks of the Crocodile River and factory effluent in $500 \mathrm{~mL}$ sampling bottles using grab sampling. A factory effluent water the wastewater discharged from the mining operations. The samples were collected in December (summer season). The bottles were rinsed with the surface water before collecting each sample $15 \mathrm{~cm}$ below surface water at each sampling point. The water samples were acidified with $\mathrm{HNO}_{3}$ and the physicochemical parameters were also measured at the field.

\subsection{Sample preparation}

Aqua regia was used for digestion of dust, sediments and soils samples. The temperature was maintained at $110^{\circ} \mathrm{C}$ for $2 \mathrm{~h}$ during digestion of $0.2 \mathrm{~g}$ of the samples with $20 \mathrm{~mL}$ of 3:1 $(\mathrm{v} / \mathrm{w}) \mathrm{HCl} / \mathrm{HNO}_{3}$ mixtures on a hot plate in the fume hood. After cooling, $20 \mathrm{~mL}$ of $2 \% \mathrm{HNO}_{3}$ water was added to the sample and mixed. The residue was filtered through filter paper and then the sample was diluted to $100 \mathrm{~mL}$ with de-ionised water. A bulk dust sample was prepared through modified BCR sequential extraction as explained by Wali et al. [22]. In the laboratory, the water samples were passed through a $0.45 \mu \mathrm{m}$ membrane filter prior to analysis. ICP-OES instrument was used to determine the concentrations of PGMs in the solutions. The dust samples were air-dried in open air, to remove moisture content. Removal of moisture is significant because moisture content above $20 \%$ could interfere with the XRF analysis and also alter the soil matrix for which the XRF spectrometer has been calibrated with respect to solid (powdered) samples. The soil samples were thoroughly homogenized and sieved into fine particle sizes of $75 \mu \mathrm{m}$ with Retsch aluminium test-sieves with vibratory electronic sieve shaker to reduce soil matrix. In general, although results are element dependent, sieving samples to a particle size of $<250 \mu \mathrm{m}$ is recommended [23]. For measurements of $\mathrm{pH}$ and EC, 1:5 sample (dust or soil or sediment) to deionized water suspension (w/v) mixture was prepared. A portable Multi-probe Boeco $\mathrm{pH}$ meter purchased from Rochelle (Johannesburg, South Africa) was used to measure the $\mathrm{pH}$ and electrical conductivity (EC).

\section{Results and discussion}

\subsection{Characterisation of water and dust samples}

Table 2 shows the results for $\mathrm{pH}$, electrical conductivity (EC), total dissolved solids (TDS) and temperature of collected water samples from the Crocodile River. The $\mathrm{pH}$ ranged from 7.7 to 8.7 which shows that the $\mathrm{pH}$ was just above the neutral $\mathrm{pH}$ of 7 . The highest $\mathrm{pH}$ value was 8.7, which was recorded along the river close to the cement plant and the lowest value was 7.7 due to neutralization of the plant wastewater by liming the effluent from the 
Table 2 Physico-chemical properties of water samples from the Crocodile River

\begin{tabular}{|c|c|c|c|c|c|}
\hline Site & GPS coordinates & $\mathrm{pH}$ & $\mathrm{EC}\left(\mathrm{mS} \mathrm{cm}^{-1}\right)$ & TDS $\left(\mathrm{mg} \mathrm{L}^{-1}\right)$ & $\begin{array}{l}\text { Tem- } \\
\text { perature } \\
\left({ }^{\circ} \mathrm{C}\right)\end{array}$ \\
\hline $\mathrm{Cr} 1$ & $\begin{array}{l}25^{\circ} 05^{\prime} 89 \mathrm{~S} \\
27^{\circ} 51^{\prime} 99 \mathrm{E}\end{array}$ & 7.9 & 529 & 316 & 29.2 \\
\hline $\mathrm{Cr} 2$ & $\begin{array}{l}25^{\circ} 06^{\prime} 62 \mathrm{~S} \\
27^{\circ} 51^{\prime} 57 \mathrm{E}\end{array}$ & 8.1 & 510 & 301 & 30.9 \\
\hline $\mathrm{Cr} 3$ & $\begin{array}{r}25^{\circ} 07^{\prime} 21 \mathrm{~S} \\
27^{\circ} 52^{\prime} 05 \mathrm{E}\end{array}$ & 7.9 & 491 & 324 & 30.0 \\
\hline $\mathrm{Cr} 4$ & $\begin{array}{r}24^{\circ} 89^{\prime} 14 \mathrm{~S}, \\
27^{\circ} 51^{\prime} 99 \mathrm{E}\end{array}$ & 8.7 & 464 & 285 & 32.2 \\
\hline $\mathrm{Cr} 5$ & $\begin{array}{r}24^{\circ} 89^{\prime} 43 \mathrm{~S} \\
27^{\circ} 52^{\prime} 45 \mathrm{E}\end{array}$ & 8.5 & 486 & 291 & 27.0 \\
\hline Cr6 & $\begin{array}{r}24^{\circ} 89^{\prime} 94 \mathrm{~S} \\
27^{\circ} 52^{\prime} 95 \mathrm{E}\end{array}$ & 8.5 & 485 & 292 & 27.7 \\
\hline Crp & $\begin{array}{l}24^{\circ} 98^{\prime} 22 \mathrm{~S} \\
27^{\circ} 54^{\prime} 82 \mathrm{E}\end{array}$ & 7.7 & 1073 & 630 & 33.7 \\
\hline
\end{tabular}

Cr1-Cr6 are the sampling points of water along the Crocodile River and $\mathrm{Crp}$ is the sampling point of water at the effluent outside the cement plant

cement plant. This $\mathrm{pH}$ from the effluent showed that the water was almost clean which implies it was treated before being released to the Crocodile River. The $\mathrm{pH}$ values fell within the recommended limit of 6-8.5 set by World Health Organisation and adopted by the Department of Water Affairs and Forestry of South Africa [24] for domestic, recreation and agricultural water use.

$E C$ is used as a measure of the mineral or ionic concentration of water [25]. EC of the Crocodile River water samples is shown in Table 2. The EC values ranged from 510 to $1073 \mu \mathrm{S} \mathrm{cm}^{-1}$. The highest conductivity of $1073 \mu \mathrm{S} \mathrm{cm}^{-1}$ was observed for water collected in the factory effluent next to the cement plant. This indicated that the water from the cement plant carried high mineral content. The EC values obtained in this study exceeded the water guidelines set by DWAF [24] and WHO [26].

TDS of water samples from the Crocodile River and factory effluent ranged from 301 to $630 \mathrm{mg} \mathrm{L}^{-1}$. TDS is the measure of dissolved mineral ions in water such as magnesium, calcium, sulphate, chloride, bicarbonate, sodium, nitrate and carbonate. It is a direct estimate of electrical conductivity of water because EC is the measure of charged ions in the solution [24]. The highest value of $630 \mathrm{mg} \mathrm{L}^{-1}$ from factory effluent (Crp) was above the recommended limit of DWAF [27] for domestic water use $450 \mathrm{mg} \mathrm{L}^{-1}$ and higher than the guideline value of $\left(0.4 \mathrm{mg} \mathrm{L}^{-1}\right)$ for use in irrigation. The temperature values of the water samples ranged from 27 to as high as $33.7^{\circ} \mathrm{C}$. The overall higher temperature was recorded over the factory effluent which was flowing slowly and during
Table 3 Physico-chemical characteristic of dust and sediment samples

\begin{tabular}{llllll}
\hline Sample & CR1 & CR3 & RS8 & RS16 & Bulk \\
\hline Ph & 7.3 & 8.2 & 7.8 & 6.7 & 8.0 \\
EC $\left(\mu \mathrm{s} \mathrm{cm}^{-1}\right)$ & 791 & 366 & 362 & 986 & 1497 \\
\hline
\end{tabular}

CR1 and CR3 are the sediment samples collected along the Crocodile River, RS8 and RS16 are the dust sample collected along the road, Bulk is the dust sample collected in bulk next to the cement plant

summer period. Higher temperatures above $30^{\circ} \mathrm{C}$ affect organisms such as crabs, fish and microorganisms because it decreases the amount of dissolved oxygen in water. Factory effluent had the highest temperature of $33^{\circ} \mathrm{C}$ as it is open to direct sunlight which increases the temperature of water.

The $\mathrm{pH}$ and $\mathrm{EC}$ of the dust and sediment samples were determined to assess their possible influences on agricultural soil. The $\mathrm{pH}$ of the dust samples measured varied from 6.7 to 8.2 , and this range showed that the dust was slightly alkaline. The alkalinity of the dust might have been caused by the presence of high calcium carbonate content present in dust. The highest $\mathrm{pH}$ value of 8.2 was observed at the bottom surface sediment collected along the Crocodile River. This suggested that there was high percolation of lime on sediments.

The EC values of the dust and sediments samples are shown in Table 3. The recorded values of EC varied from 362 to $1497 \mu \mathrm{S} \mathrm{cm}^{-1}$. The highest EC value was observed for sample collected next to the cement plant were most of the dust emanating from the plant settled. This shows that the dust was predominantly loaded with ions. Such ions might be have been carried by dust from the cement plant. The ions might be magnesium, sulphate, carbonate, chloride and calcium from limestone and clay. These elements may affect productivity of the agriculture soil of the farms situated along the gravel road. The dust sample (RS16) collected along the road was slightly acidic, and this $\mathrm{pH}$ was strongly influenced by traffic activities. The other sources of heavy metal contamination on roads were from tire and brake abrasion, combustion exhausts $[28,29]$ and discharges of some raw material elements for cement production carried by heavy vehicles.

\subsection{Mineralogy of dust samples}

The XRD pattern of the dust samples collected close to the cement plant is shown in Fig. 2. The mineralogy of the dust sample was recorded for the sample in order to know about the mineralogical composition and the crystalline nature of samples. The minerals contained in the samples were identified by making use of International Centre for 


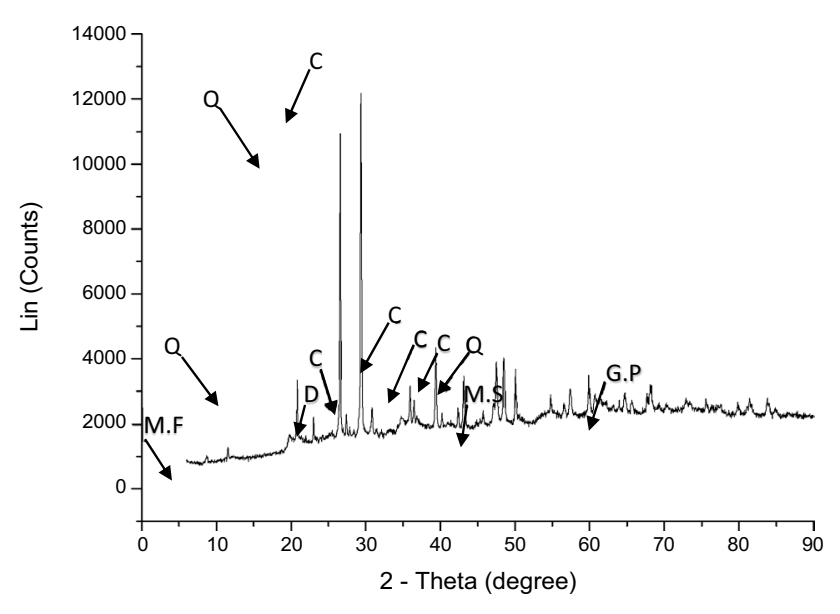

Fig. 2 A representative XRD diffractogram (Q Quartz, M.F. Microline Feldspar, M.S. Muscivite, G.P. Gypsum, C Calcite, D Dolomite) of the minerals present in the bulk sample

Table 4 Shows the concentration of heavy metals and metals oxides with their standard deviations obtained using the XRF analysis of the bulk sample collected close to the cement plant

\begin{tabular}{lll}
\hline Heavy metals & Concentration $\left(\mathrm{mg} \mathrm{kg}^{-1}\right)$ & $\mathrm{SD}$ \\
\hline $\mathrm{Pt}$ & $\mathrm{bdl}$ & $\mathrm{bdl}$ \\
$\mathrm{Pd}$ & $\mathrm{bdl}$ & bdl \\
$\mathrm{Rh}$ & $\mathrm{bdl}$ & $\mathrm{bdl}$ \\
$\mathrm{Ni}$ & 0.002 & 0.002 \\
$\mathrm{Metal}$ oxides & & \\
$\mathrm{Al}_{2} \mathrm{O}_{3}$ & 9.55 & 0.26 \\
$\mathrm{SiO}_{2}$ & 38.43 & 0.36 \\
$\mathrm{CaO}$ & 15.72 & 0.05 \\
\hline
\end{tabular}

SD standard deviation, $b d l$ below detection (0.001 ppm)
Diffraction Data, Powder Diffraction File (ICDD PDF). The XRD pattern identified the following minerals; quartz, calcite, dolomite, microcline, muscovite and gypsum. These minerals observed in the XRD patterns of dust represent the composition of raw materials used in cement manufacturing with gypsum used as an additive for the clinker. XRD pattern also showed that quartz dominated and minerals in XRD pattern were crystalline in nature.

\subsection{XRF analysis of dust samples}

The XRF results of the bulk sample collected close to cement plant are shown in Table 4. As for this study, $\mathrm{Ni}$ was the only heavy metal observed from the XRF analysis with a concentration of $0.002 \mathrm{mg} \mathrm{kg}^{-1}$ and the Pt, Pd and $\mathrm{Rh}$ were below detection limit. The metal oxides such as silicate, lime and aluminate were the major representative of dust sample as shown in Table 4. These metal oxides might be arising from the raw materials used for cement production.

\subsection{Levels of PGMs in the Crocodile River and road dust samples}

The concentrations of $\mathrm{Pd}, \mathrm{Pt} \mathrm{Rh}$ and $\mathrm{Ru}$ in the Crocodile River where obtained from the ICP-OES with LODs ranging from 4.1 to $22.8 \mu \mathrm{g} \mathrm{L}^{-1}$. The general trend of the concentration of PGMs at each site was decreasing in the following order $\mathrm{Pt}>\mathrm{Ru}>\mathrm{Rh}>\mathrm{Pd}$. Figure 3 showed that the concentration of the PGMs generally increased moving along the sampling points in the Crocodile River. Elevated levels of the PGMs after the cement plant at sampling points $\mathrm{Cr}$, $\mathrm{Cr} 5$ and $\mathrm{Cr} 6$ might be due to contamination of water by the effluent from the cement plant, leaching of the metals to the water bodies and atmospheric deposition. High concentrations of $\mathrm{Pt}$ at all the sampling points might also be caused by large deposits of Pt in the area [30]. Gagnon
Fig. 3 Concentration of PGMs in water samples of the Crocodile River and the factory effluent

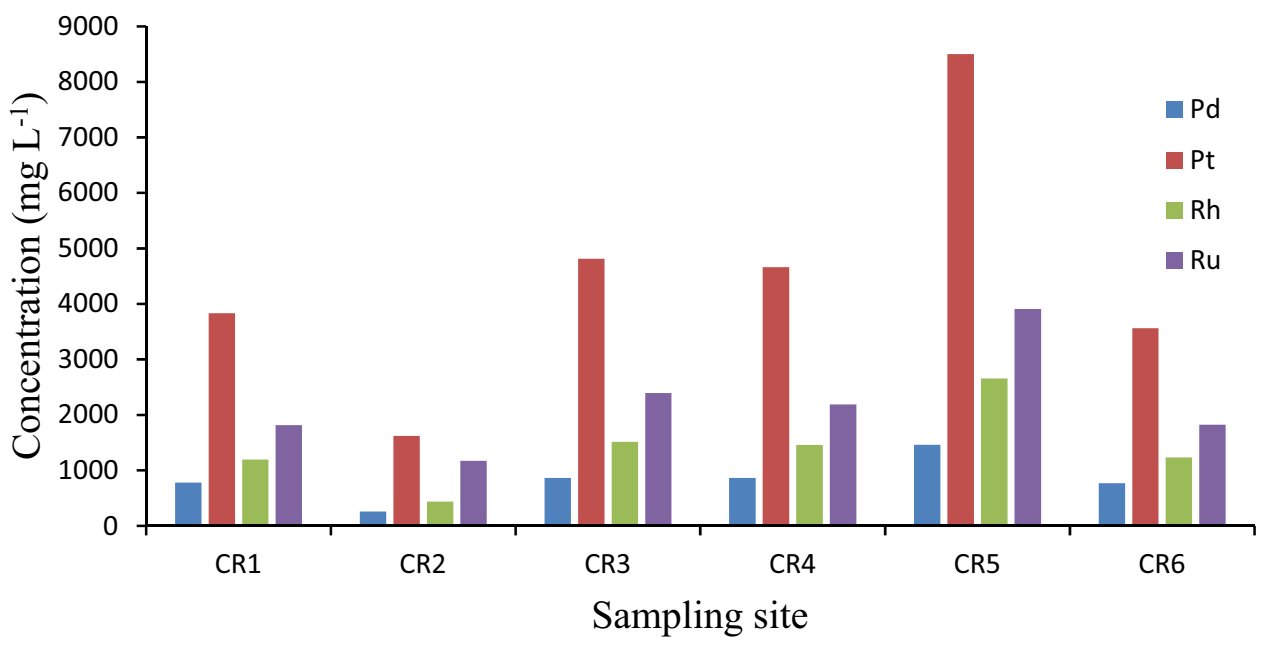


[31] reported that in highly industrialised areas, large amounts of Pt can be detected in river sediments. The presence of organic matter like humic and fulvic acids was likely to bind platinum and other PGMs. This is enhanced by having appropriate $\mathrm{pH}$ and redox potential conditions in the aquatic environment. The level of PGMs in the effluent sample showed that most of the metals in the Crocodile River emanated from the cement production plant.

Figure 4 shows the concentration of PGMs in different $B C R$ fractions. The PGMs dominated the reducible fraction (ERO), followed by exchangeable fraction (EXC), oxidizable fraction (OM) and residual fraction (RE). Generally, the availability as well as the mobility of the PGMs decreased in the following order: ERO $>E X C>O M>R E$. This study also revealed that ERO and EXC fractions constituted the highest fractions with respect to the distribution of all metals. The ERO represents the concentration of metal bound to iron and manganese oxides that would be released if the substrate was subjected to more reductive condition [32]. EXC is the fraction that gives adverse impact to the

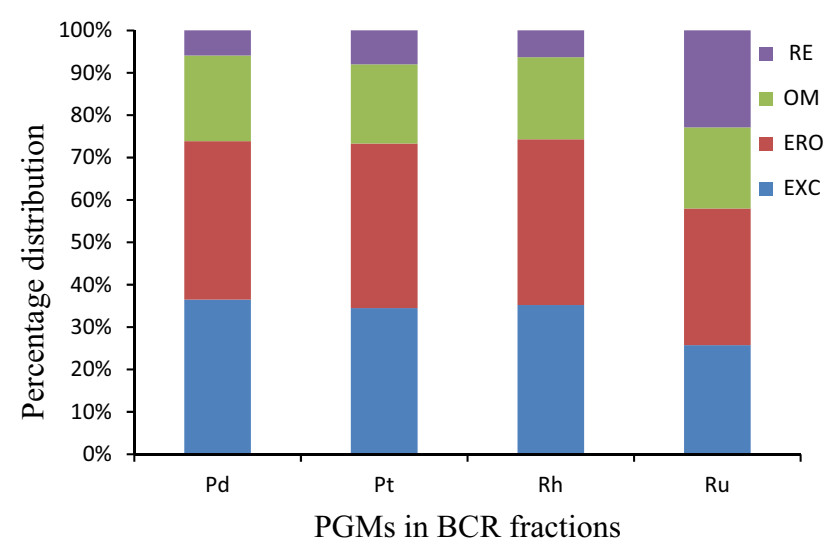

Fig. 4 Distribution of PGMs in BCR fractions with particle size of $32 \mu \mathrm{m}$ environment [33]. The observed trend order suggested that metals were bioavailable and mobile, which can result to uptake by the plants. This study also revealed that ERO and EXC fractions constituted the highest fractions with respect to the distribution of all metals. This trend also suggested that the PGMs were from anthropogenic origin because of observed high levels in the ERO and EXC fractions. The highest concentration was observed for Pt with a concentration of $32 \mathrm{mg} \mathrm{kg}^{-1}$ in the reducible fraction. $\mathrm{Pt}$ is mobile only in extremely acidic conditions or in soil water with high chloride content [31]. The availability and the mobility of metals pose a concern to the surrounding communities because people might ingest these metals through food chain.

\subsection{PGMs in different particle size fractions}

The concentration of PGMs in different particles size fractions are presented in Fig. 5. Pt dominated all particle size fractions. Most of the PGMs were associated with the smaller particle size of $\mathrm{PM}_{32}$ due to high surface areas: surface area: volume ratio and negative charges associated with fine particles especially on 2:1 clay minerals and organic matter [34]. The preference of the metals to the small particles was also observed by Wang and Chen [35]. The concentration of PGMs decreased with the increase of particle sizes. The level of the PGMs was high in small particle size fractions and the order was $\mathrm{PM}_{32}>\mathrm{PM}_{75}>\mathrm{PM}_{125}$. This showed that PGMs in smaller particle sizes pose high risk to the people because such particles can be inhaled. The particles with small sizes are considered a major environmental and health hazard [36]. The general trend of each metal in the particle size fractions was decreasing in the following order; $\mathrm{Pt}>\mathrm{Ru}>\mathrm{Rh}>\mathrm{Pd}$. Similar metal abundance order was obtained in all three different particles size fractions. The trend depicted in the Fig. 5 shows that people inhaling fine particles in the area around the
Fig. 5 PGMs concentrations in six different particle sizes fractions

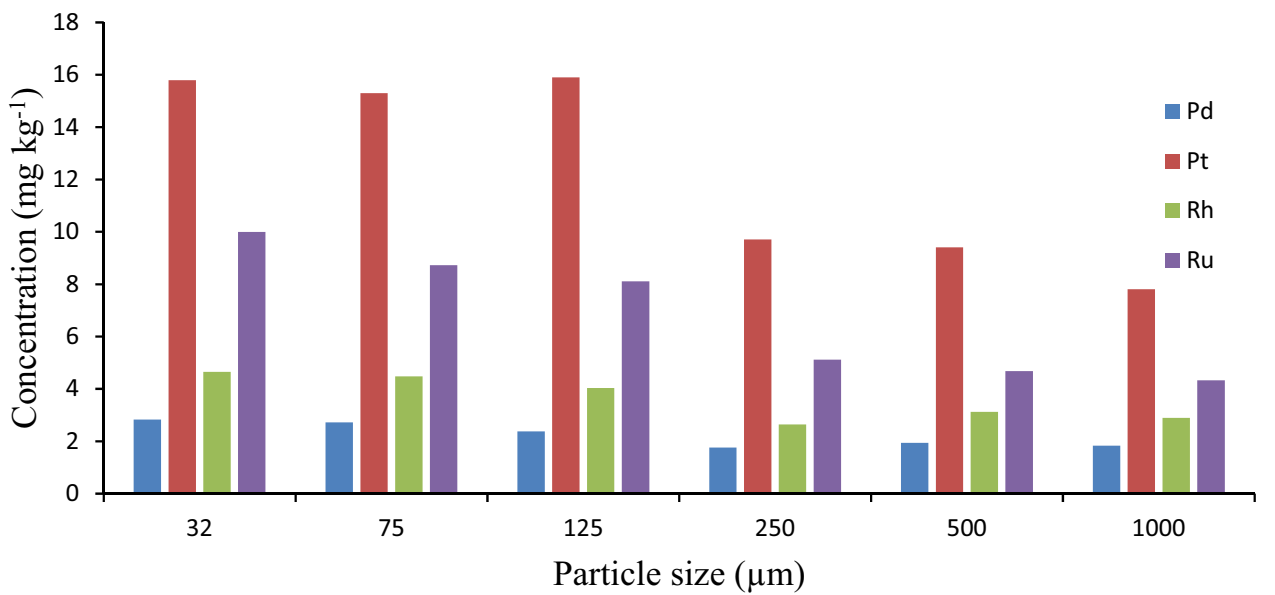

SN Applied Sciences a SPRINGER NATURE journal 
cement plant are in danger of health problems associated with PGMs toxicity. The results suggested that size distribution of particles containing PGMs is important with respect to risk assessment of human inhalation.

\subsection{Depth analysis}

The levels of PGMs at different depths of the soil samples collected next to the cement plant are shown in Fig. 6. The general trend was the decreasing of PGMs concentration with increasing depth from the topsoil to downwards. This uniform trend was observed for all PGMs from upper surface to downwards. A similar pattern was observed in Bongwha, Korea by Kim and Jung [37]. Nemati et al. [13] also found that at increasing depths, the effects of pollution become slighter and metals are always absorbed in the top soil at first, and then sinks into deeper positions by chemical exchange. This uniform trend was observed for all PGMs from upper surface to downwards. The PGMs concentration decreased with depth in the following order; $\mathrm{Pt}>\mathrm{Ru}>\mathrm{Rh}>\mathrm{Pd}$. The concentrations of the PGMs observed showed that the metals were being transferred to the lower soils by rain water.

\subsection{Spatial analysis}

The concentration of PGMs in particle size fraction of $\left(\mathrm{PM}_{32}\right)$ for dust samples collected along a gravel road are shown in Fig. 7. The highest concentrations in all the dust samples were that of $\mathrm{Pt}$ followed by $\mathrm{Ru}, \mathrm{Rh}$ and $\mathrm{Pd}$. The PGMs concentration along the dust road varied as follows Pt, (150-16,550 mg kg $\left.{ }^{-1}\right)$, Rh (58.5-5100 mg kg-1), $\mathrm{Ru}\left(381-7100 \mathrm{mg} \mathrm{kg}^{-1}\right)$ and Pd (71.5-2895 $\left.\mathrm{mg} \mathrm{kg}^{-1}\right)$. Low concentration was observed at the first sampling point (RS1) which is furthest from the cement plant. This showed that the concentrations of the PGMs decreased with the increase of distance from the cement plant. A work done by Hooda et al. [38] also showed that the concentrations of these metals decreased with the increase of distance from the dust roadway. High concentration was observed at the last sampling point (RS19) on a busy road where heavy vehicles pass by carrying cement bags and minerals. Vehicular and industrial emissions are known to be one of the major sources of metal pollution in road dust [39]. This high levels of PGMs on the dust road suggested that the dust road was polluted by emissions from the heavy vehicles and minerals falling on the road. It was observed that the concentrations of the PGMs were higher for the dust samples collected in the eastern part than those from western part of cement plant. The wind direction might have influenced the direction of atmospheric deposition of dust on the eastern part from the cement plant. High amounts of PGMs in the farm (OPP) might affect the crops.

\section{Conclusions}

In this study, the results showed that the cement plant activities increased the accumulation of PGMs in soil and water around Koedoeskop. The level of PGMs in the samples was dominated by $\mathrm{Pt}$, followed by $\mathrm{Ru}, \mathrm{Rh}$ and $\mathrm{Pd}$. The BCR method revealed that PGMs were available and mobile for the plant uptake, which pose health rick. The results indicated a preferential partitioning of metals to small particle size fractions in all samples. The dust contained minerals such as quartz, calcite, muscovite,
Fig. 6 PGMs concentrations in soil profile

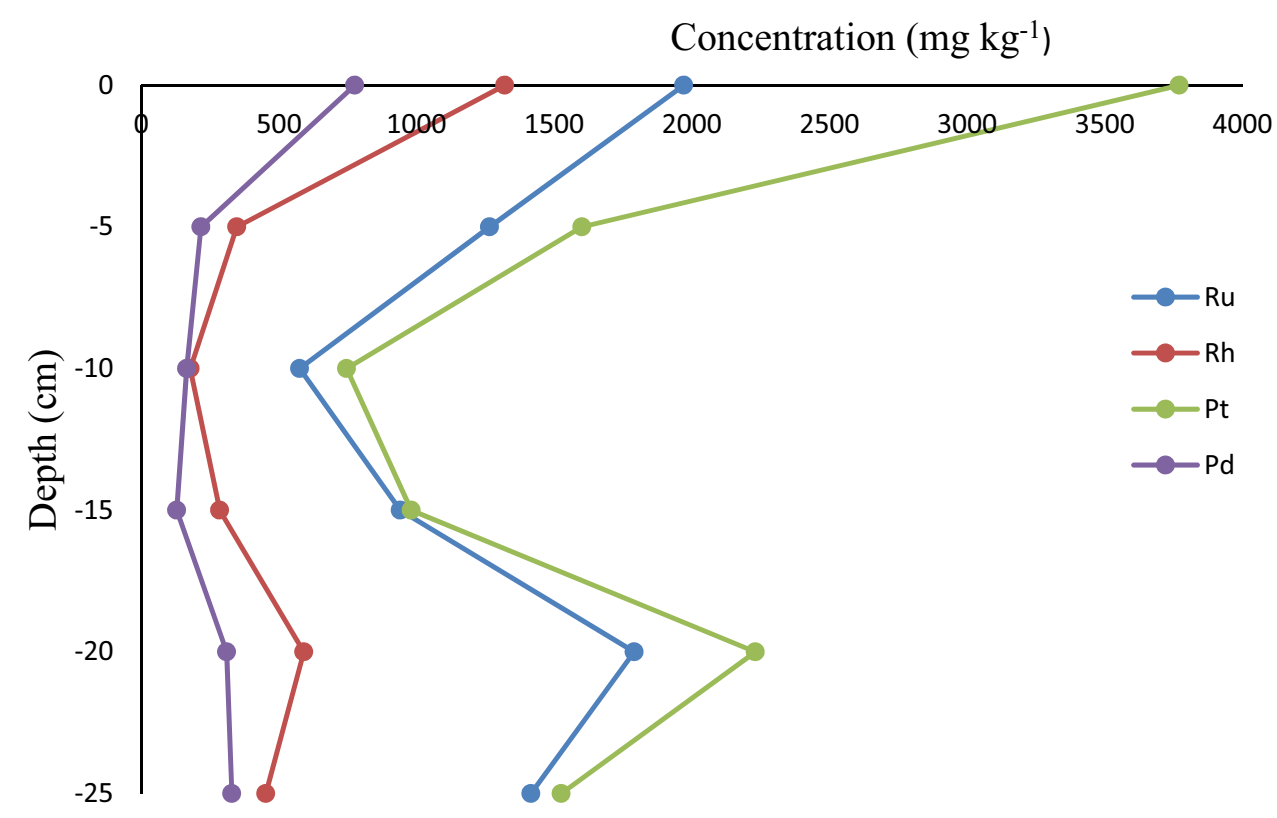

SN Applied Sciences 


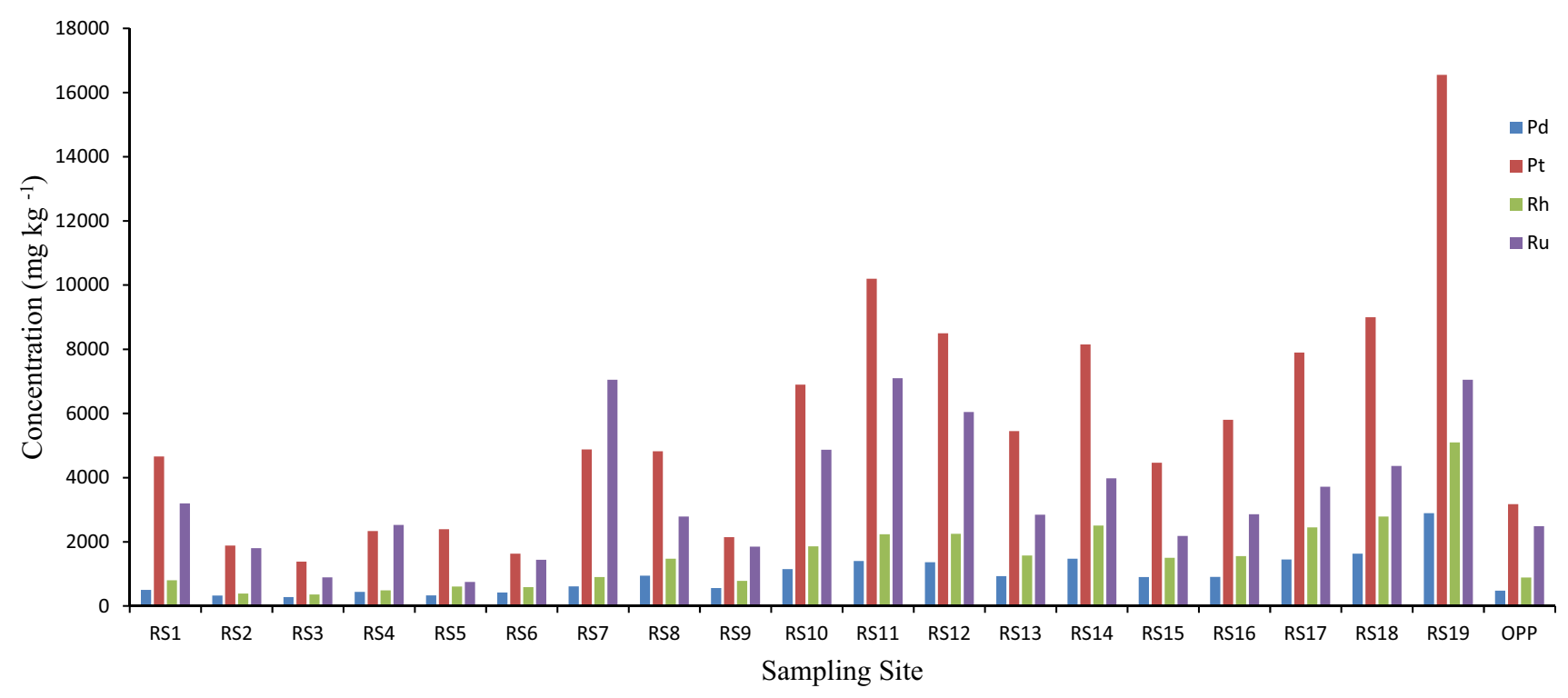

Fig. 7 Distribution of heavy metals along a dust road next to the cement plant. Note RS1-RS19 are the sampling points along a dust road next to the cement plant and OPP is the sample point on a farm next to the cement plant

dolomite, microline feldspar and gypsum. Dust road was highly contaminated with the PGMs especially in next to the cement plant and along the busy road. This study showed that monitoring and risk assessment are necessary to evaluate the PGMs concentration in dust in order to develop the proper measures for reducing health effects associated with inhalation and ingestion of dust. High level of PGMs showed that the water suppressant was not effectively suppressing the PGMs on the dust road. An efficient method that can suppress dust with the PGMs is required to avoid resuspension of the PGMs with dust, which pose health hazard to the people in the surrounding communities next to the cement plant.

Acknowledgements The authors would like to thank the Department of Chemistry at University of Venda, National Research Foundation (NRF) and SASOL Inzalo Foundation for financial assistance and University of Limpopo for the analysis of dust, soil and water samples with the ICP-OES instrument.

\section{Compliance with ethical standards}

Conflict of interest The authors declare that they have no conflict of interest.

\section{References}

1. Niemelä M, Perämäki P, Piispanen J, Poikolainen J (2004) Determination of platinum and rhodium in dust and plant samples using microwave-assisted sample digestion and ICP-MS. Anal Chim Acta 521:137-142
2. Rao CRM, Reddi GS (2000) Platinum group metals (PGM): occurrence, use and recent trends in their determination. Trac Trend Anal Chem 19(9):565-586

3. Saffari A, Ataei M, Sereshki F, Naderi M (2017) Environmental impact assessment (EIA) by using the Fuzzy Delphi Folchi (FDF) method (Case study: Shahrood Cement Plant, Iran)

4. Kalafatoglu E, Ors N, Ozdemir SS, Munlafalioglu I (2001) Trace element emissions from some cement plants in Turkey. Water Air Soil Poll 129:91-100

5. Feig GT, Naidoo S, Ncgukana N (2016) Assessment of ambient air pollution in the Waterberg Priority Area 2012-2015. CLEAN-Soil Air Water 26(1):21-28

6. U.S. Environmental Protection Agency (1994) Emission factor documentation for AP-42, section 11.6: Portland Cement Manufacturing, Final report, EPA Contract 68-D2-0159, MRI Project

7. Nurbiyantoro S (2010) Pengaruh Polusi Udara Terhadap Fungsi Paru-Paru Polisi Lalu Lintas. DiSurakarta UNS, Surakarta, pp 44-45

8. Farhadloo MRP, Akbari I, Shabestari SS, Shabestar DS (2016) Reduce dust pollution using water suppression, conference: the 8 th national conference \& exhibition on environmental engineering, At Tehran University, Tehran, Iran

9. Barnard M (2014) Dermal exposure to platinum group metals at a precious metal refinery: a pilot study (Doctoral dissertation)

10. U.S. Environmental Protection Agency (1998) Report to Congress Public Comment Summary and Response Document on Cement Kiln Dust. Office of Solid Waste, Washington, DC

11. Petavratzi E, Kingman S, Lowndes I (2005) Particulates from mining operations: a review of sources, effects and regulations. Miner Eng 18(12):1183-1199

12. Khattak Z, Ahmad J, Ali HM, Shah S (2013) Contemporary dust control techniques in cement industry, electrostatic precipitator - A Case Study. World Applied Sciences Journal 22(2):202-209

13. Nemati K, Abu Bakar NK, Radzi Abas M, Sobhanzadeh E (2011) Speciation of heavy metals by modified $B C R$ sequential extraction procedure in different depths of sediments from Sungai Buloh, Selangor. Malaysia. J Hazard Mater 192(1):402-410 
14. Aiju L, Yanchun G, Honghai W, Gao Peiling G (2012) An assessment of heavy metals contamination in Xiaofu River sediments through chemical speciation study. Int J Earth Sci 5(5):1235-1240

15. Saracoglu S, Soylak M, Elci L (2009) Extractable trace metals contents of dusts of air filters from vehicles by sequential extraction procedure. JAOC 92:1196-1202

16. Ražic S, Dogo S (2010) Determination of chromium in Mentha piperita $\mathrm{L}$. and soil by graphite furnace atomic absorption spectrometry after sequential extraction and microwave-assisted acid digestion to assess potential bioavailability. Chemosphere 78(4):451-456

17. Pérez-Moreno SM, Gázquez MJ, Pérez-López R, Bolivar JP (2018) Validation of the $B C R$ sequential extraction procedure for natural radionuclides. Chemosphere 1(198):397-408

18. Diong HT, Das R, Khezri B, Srivastava B, Wang X, Sikdar PK, Webster RD (2016) Anthropogenic platinum group element (Pt, Pd, $\mathrm{Rh})$ concentrations in PM 10 and PM 2.5 from Kolkata, India. SpringerPlus 5(1):1242

19. Liu Y, Tian F, Liu C, Zhang L (2015) Platinum group elements in the precipitation of the dry region of Xinjiang and factors affecting their deposition to land: the case of Changji City, China. Atmos Pollut Res 6:178-183

20. Rauch S, Peucker-Ehrenbrink B (2015) Sources of platinum group elements in the environment. In: Zereini F, Wiseman CLS (eds) Platinum metals in the environment. Springer, Heidelberg, pp 3-17

21. Govinda H, Khumalo J, Mkhwanazi S (2016) Estimating the benefits of anti-cartel interventions: the case of the South African cement cartel. In: Competition Law Enforcement in the BRICS and in Developing Countries, pp 309-336

22. Wali A, Colinet G, Ksibi M (2014) Speciation of heavy metals by modified BCR sequential extraction in soils contaminated by phosphogypsum in Sfax. Tunisia. Environmental Research. Eng Manag 4(70):14-26

23. Urrutia-Goyes R, Hernandez N, Carrillo-Gamboa O, Nigam KDP, Ornelas-Soto N (2018) Street dust from a heavily-populated and industrialized city: evaluation of spatial distribution, origins, pollution, ecological risks and human health repercussions. Ecotox Environ Safe 159:198-204

24. DWAF (1996) South African Water Quality Guidelines (2nd edn). Domestic Use 1(1):116-118

25. Singo NK (2013) An assessment of heavy metal pollution near an old copper mine dump in Musina, University of South Africa, South Africa (Doctoral dissertation)

26. WHO (2011) Guidelines for drinking-water quality. WHO Chronicle 38(4):104-108

27. DWAF (2001) Quality of domestic water supplies assessment guide, 3rd print, 2nd edn, vol 1. Water Research Commision, Pretoria, South Africa
28. Gunawardana C, Goonetilleke A, Egodawatta P, Dawes L, Kokot $S$ (2012) Role of solids in heavy metals buildup on urban road surfaces. J Environ Eng 138:490-498

29. Shaw SB, Marjerison RD, Bouldin DR, Parlange JY, Walter T (2012) Simple model of changes in stream chloride levels attributable to Road salt application. J Environ Eng 138:112-118

30. Cawthorn RG (2010) The platinum group element deposits of the Bushveld Complex in South Africa. Platin Metals Rev 54(4):205-215

31. Gagnon ZE, Newkirk C, Hicks S (2006) Impact of platinum group metals on the environment: a toxicological, genotoxic and analytical chemistry study. J Environ Sci Health, Part A 41(3):397-414

32. Panda D, Subramanian V, Panigrahy RC (1995) Geochemical fractionation of heavy metals in Chilka lake-a tropical coastal lagoon. Environ Geol 26:199-210

33. Long Y, Hu L, Fang C, Wu Y, Shen D (2009) An evaluation of the modified $B C R$ sequential extraction procedure to assess the potential mobility of copper and zinc in MSW. Microchem J 91:1-5

34. Acosta JA, Cano AF, Arocena JM, Debela F, Martínez-Martínez S (2009) Distribution of metals in soil particle size fractions and its implication to risk assessment of playgrounds in Murcia City (Spain). Geoderma 149(1-2):101-109

35. Wang XS, Qin Y, Chen YK (2006) Heavy meals in urban roadside soils, Part 1: effect of particle size fractions on heavy metals partitioning. Environ Geol 50(7):1061-1066

36. Homolya J (1999) Particulate matter (PM25) Speciation Guidance Document. January 21, PA

37. Kim MJ, Jung Y (2004) Vertical distribution and mobility of arsenic and heavy metals in and around mine tailings of an abandoned mine. J Environ Sci Health, Part A 39(1):203-222

38. Hooda PS, Miller A, Edwards AC (2008) The plant availability of auto-cast platinum group element. Environ Geochem Health 30:135-139

39. Yuen JQ, Olin PH, Lim HS, Benner SG, Sutherland RA, Ziegler AD (2012) Accumulation of potentially toxic elements in road deposited sediments in residential and light industrial neighbourhoods of Singapore. J Environ Manag 101:151-163

Publisher's Note Springer Nature remains neutral with regard to jurisdictional claims in published maps and institutional affiliations. 